\title{
Kamila Budrowska
}

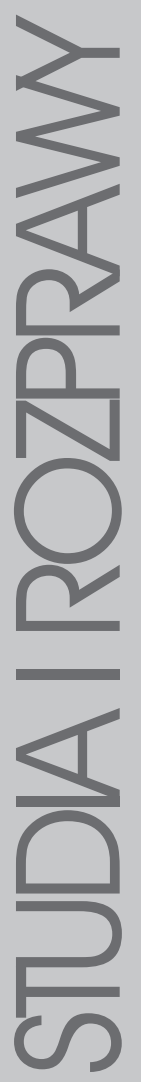

Kamila Budrowska - doktor habilitowany, pracuje na stanowisku profesora na Wydziale Filologicznym UwB. Kieruje Ośrodkiem Badań Filologicznych nad Cenzurą PRL, którego prace finansowane są z grantu przyznanego przez MNiSW w ramach projektu "Narodowy Program Rozwoju Humanistyki" na lata 2012-2017. Publikowała w "Pamiętniku Literackim”, „Tekstach Drugich”, "Napisie”, "Wieku XIX" i pracach zbiorowych. Autorka monografii Literatura i pisarze wobec cenzury PRL. 1948-1958 (2009). Stypendystka Fundacji na rzecz Nauki Polskiej. Zainteresowania naukowe: cenzura w PRL, tekstologia i edytorstwo naukowe, proza najnowsza, gender. 


\section{O niestosownych zastosowaniach literatury w cenzorskich materiałach instruktażowych}

zasobach archiwalnych pozostawionych przez GUKPPiW (Główny Urząd Kontroli Prasy Publikacji i Widowisk) znaleźć można bardzo interesujący typ dokumentu, obejmujący lata 1957-1960 - „Sygnały”. Jest to poufny, wewnętrzny biuletyn urzędu, prawdopodobnie rozsyłany do wszystkich oddziałów w celach informacyjnych oraz - co ważne dla niniejszych rozważań - instruktażowych. „Sygnały” zawierają maszynopisy zakwestionowanych tekstów bądź ich fragmentów (teksty literackie i nieliterackie), w niektórych wypadkach z oceniającym komentarzem; jeden utwór stanowi jeden „Sygnał”.

$\mathrm{W}$ dokumentach z lat wcześniejszych się nie pojawiają (nie wiemy, czy ich nie sporządzano, czy może się nie zachowały), potem zaś, z pewną regularnością, przygotowuje się je w latach 60. i 70. Istotność „Sygnałów” na tle innych archiwaliów polega na tym, że rejestrują w sposób systematyczny i zachowują - niejako wbrew obowiązującemu nakazowi niszczenia egzemplarzy korektowych - wycinane teksty bądź ich fragmenty. Wprawdzie i w innych zespołach natrafić można na maszynopisy bądź rękopisy zakwestionowanych dzieł (nakaz niszczenia nie był przestrzegany skrupulatnie), ale zwykle w niekompletności, rozproszeniu pomiędzy dokumentami różnego typu i z różnych lat. Tu zaś mamy zbiór systematyczny, który może mieć duże znaczenie zarówno jako materiał pozwalający zrozumieć dynamikę cięć, jak i materiał do przyszłych prac edytorskich. Do zebrania oraz wewnętrznego uporządkowania „Sygnałów” przyczynił się, najprawdopodobniej przyświecający ich twórcom, cel dydaktyczny. Wszystkie „Sygnały” z 1957 roku dotyczą nieudanych publikacji w prasie społeczno-kulturalnej i literackiej, późniejsze - z lat 1958-1960 - mieszczą również pojedyncze przypadki tekstów zgłaszanych do wydania jako wydawnictwa nieperiodyczne. Zawsze jednak są to teksty krótkie: pojedyncze wiersze, niedługie opowiadania, fragmenty większych całości.

Jak wynika z kwerendy obejmującej archiwalia z lat 1945-1960, materiałów instruktażowych, informacyjnych, wszelkiego rodzaju sprawozdań, podsumowań urząd produkował

* Praca naukowa finansowana w ramach programu Ministra Nauki i Szkolnictwa Wyższego pod nazwą „Narodowy Program Rozwoju Humanistyki" w latach 2012-2017.

1 AAN, GUKPPiW, 594, teczki 62/1-62/4. 
bardzo wiele 2 . Prócz „Sygnałów” wymienić można „Biuletyn Informacyjno-Instrukcyjny”, „Przeglądy ingerencji”, „Sprawozdania opisowe”, „Sprawozdania okresowe”, „Odprawy krajowe", tworzone zarówno przez oddziały wojewódzkie (tu głównie opis bieżącej działalności), jak i centralę (opis aktywności bieżącej oraz projekty i założenia dotyczące działalności planowanej). Wszystkie dokumenty sporządzane w urzędach cenzury nosiły klauzulę tajności: zawarte w nich informacje nie mogły przedostać się do opinii publicznej, zgodnie z zasadą ukrywania przed społeczeństwem samego istnienia GUKPPiW. Ale część wzmiankowanych zespołów, na przykład „Sprawozdania okresowe”, „Odprawy krajowe”, była tajna także dla szeregowych pracowników urzędu kontroli.

Tu warto postawić pytanie, na które przyjdzie odpowiedzieć w innym miejscu, skąd potrzeba tworzenia tak wielu metamateriałów? Czy chodziło przede wszystkim o sprawny przepływ informacji pomiędzy oddziałami, czy też główny nacisk kładziono się na szkolenie: prezentowanie wskazówek przydatnych przy kontroli poszczególnych typów tekstów, tropienie błędów i przeoczeń. A może celem było stworzenie iluzji GUKPPiW jako instytucji generującej ogromną ilość dokumentów, a więc instytucji samodzielnej? O pełnej zależności od PZPR i rządu oraz niepewnym statusie prawnym urzędu kontroli piszą wszyscy zajmujący się problematyką ${ }^{3}$, tu przypomnę jedynie, że 1) wszelkie dyrektywy dotyczące zasad cenzurowania przychodziły na Mysią z zewnątrz, 2) GUKPPiW powoływał do życia d e k r e t, co - przy jednoczesnym konstytucyjnym zapisie gwarantującym wolność słowa - powodowało chaos prawny.

$\mathrm{W}$ niniejszym artykule chciałabym opisać najciekawsze pozycje zamieszczone w „Sygnałach 1957-1960"4 by zaprezentować charakterystyczny typ manipulacji, a więc n i es to s own e go z a s t o s ow a n i a tekstu literackiego. Szczęśliwie dla badaczy w Archiwum Akt Nowych w Warszawie zachowały się liczne dokumenty z tego okresu, co przy lakoniczności oraz nieścisłościach pojawiających się w materiałach GUKPPiW jest nie do przecenienia. Jako kontekst potraktuję więc „Przeglądy ingerencji 1958”5 (w rzeczywistości mieszczące materiały datowane od sierpnia 1957 do końca 1960), „Sprawozdania okresowe WUKPPiW $1959^{\prime \prime}$ oraz sprawozdania z kontroli poszczególnych dzieł rozproszone w zespołach wydawnictw.

Lata 1957-1960 w zmiennej historii cenzurowania literatury polskiej, najściślej rzecz jasna związanej z rytmem przemian politycznych, zasługują na baczną uwagę. Po zaostrzeniu działań cenzury w połowie 1948 roku i utrzymaniu „ostrego kursu” do początków 1955 roku, przychodzi fala liberalizmu związana z przemianami październikowymi, a najłagodniejsza cenzura obowiązuje pomiędzy październikiem 1956 a październikiem 1957 roku Natomiast 1958 rok okazuje się kolejnym przełomem, charakteryzującym się odchodzeniem od ulgowego traktowania dzieł i zamykaniem dopuszczonych na krótko tematów

\footnotetext{
2 Z ustaleń P. Perkowskiego wynika, że podobnie było i w latach późniejszych, P. Perkowski, Działalność Głównego Urzędu Kontroli Prasy, Publikacji i Widowisk w latach siedemdziesiątych, niepublikowany maszynopis rozprawy doktorskiej napisanej pod kierunkiem dr hab. B. Okoniewskiej, prof. UG, Gdańsk 2005.

3 Dokumenty do dziejów PRL. Główny Urząd Kontroli Prasy 1945-1949, z. 6, opr. D. Nałęcz, Warszawa 1994; A. Paczkowski, Cenzura 1946-1949: statystyka działalności, „Zeszyty Historyczne” 1996, z. 116, s. 22-57; A. Krawczyk, Próba indoktrynacji. Działalność MliP (1944-1947), Warszawa 1994; A. Pawlicki, Kompletna szarość. Cenzura w latach 1965-1972. Instytucja i ludzie, Warszawa 2001.

4 AAN, GUKPPiW, 594.

5 AAN, GUKPPiW, 591.

6 AAN, GUKPPIW, 592.

7 J. Eisler, List 34, Warszawa 1993.
} 
i poetyki. Precyzyjne określenie momentu powrotu do rygorystycznej kontroli jest trudne. Subtelne zmiany następują począwszy od późnej jesieni 1957 roku, by już od połowy 1958 wyraźnie nosić znamiona „zaostrzenia kursu”.

Następujący bezpośrednio po Październiku okres jest, jeśli chodzi o cenzurowanie literatury, o tyle ciekawy - a podobnie rzecz się miała przy radykalizowaniu zasad kontroli w końcu 1948 - że w okresie zmian ścierają się ze sobą „stare” i „nowe” werdykty, „stare” $\mathrm{i}$ „nowe” teksty. Wiele decyzji podejmowanych jest pośpiesznie, a niepewni obowiązujących wytycznych urzędnicy GUKPPiW oraz zgłaszający utwory do kontroli pracownicy wydawnictw popełniają błędy. Ślady takiego zamieszania widać w zachowanej dokumentacji; bardzo wyraźnie w metadokumentach: sygnałach, sprawozdaniach okresowych, przeglądach ingerencji. Z „Sygnałów 1957-1960” i „Przeglądu ingerencji 1958” wynika przede wszystkim, że rzeka liberalnych, „odwilżowych” dzieł literackich jeszcze nie wyschła: niektóre utwory leżały za długo w wydawnictwie, część przetrzymano w urzędzie cenzury (niejednokrotnie aż kilka lat), niektórzy autorzy zwlekali z publikacją, nie przewidując rychłego końca „odwilży". Stąd w 1958, 1959, a nawet jeszcze w 1960 roku cenzurowane są w GUKPPiW teksty, z punktu widzenia władzy, problematyczne. Będą one podlegać, po pierwsze, bardzo rygorystycznej kontroli, po drugie - swoistej wielopoziomowej manipulacji.

Kilka przykładów.

Symptomatyczne wydają się losy wydawnicze zbioru Marka Nowakowskiego Ten stary złodziej ${ }^{8}$. Część opowiadań była w latach 1957-1958 publikowana w prasie, a więc już raz dopuszczona do druku: opowiadanie Kwadratowy ogłoszono w „Nowej Kulturze” z 1957 w numerze 31, Ożenili w „Nowej Kulturze” 1957 nr 50, tekst Umierający paser w numerze 20 „Współczesności” z 1958, a W komisariacie w numerze 28 „Współczesności” z tego samego roku, opowiadanie Tapeta pojawiło się w „Nowej Kulturze” 1958 nr 23, a Trzyczwartak w „Twórczości” z $1958 \mathrm{nr} 4$.

Jednakże, gdy wydawnictwo „Czytelnik” zgłosiło 3 października 1958 roku do GUKPPiW chęć wydania całego zbioru (łącznie ukazało się w nim 14 opowiadań), pojawiły się zastrzeżenia nie tylko do nieznanych jeszcze odbiorcom opowiadań, ale i wymowy całego tomu. Recenzję, sporządzoną 17 października przez cenzorkę Marię Burczyn, przytaczam w całości:

Jest to zbiór opowiadań częściowo już drukowanych w naszej prasie literackiej. Ukazują one życie bardzo specjalnych środowisk, jakby z peryferii naszego społeczeństwa. Bohaterami opowiadań są ludzie ze świata przestępczego, trudniący się, że tak powiem, zawodowo, z dziada pradziada, złodziejstwem, paserstwem itp. zajęciami. Ukazuje też autor środowisko drobnych handlarzy bazarowych, stojących o krok od kolizji z prawem, bądź też pisze o nieciekawym życiu drobnomieszczan z dalekich przedmieść stolicy czy też z małych miasteczek.

Ze specjalnym znawstwem i realizmem oddaje autor specyfikę i całą swoistą egzotykę świata przestępczego. Autor dobrze zna problemy i konflikty tego świata, jego obyczaje, język, pewien rodzaj etyki, przejawy solidarności „zawodowej”, cwaniactwa i znośnie pojętego bohaterstwa. Charakterystyczne jest pod tym względem opowiadanie „Kwadratowy”, który w więzieniu łyka ostre przedmioty, by przez śmierć znaleźć drogę do wolności, czy też „Cela osiemdziesiąta ósma”, ukazujące solidarną postawę złodziei wobec „kapusia” w celi.

\footnotetext{
${ }^{8}$ M. Nowakowski, Ten stary złodziej. Opowiadania, Warszawa 1958.
} 
Autor jest bardzo obiektywnym malarzem przestępczego środowiska - ani go nie potępia, ani chwali. Pokazuje po prostu mały świat złodziejski, nie siląc się na żadne uogólnienia, co do np. społecznych źródeł upadku tych ludzi czy też perspektyw ich odrodzenia. Można nawet powiedzieć, że traktuje swoich bohaterów pobłażliwie, a nawet z lekką nutą sympatii, starając się ukazać, że w każdym z nich drzemie coś ludzkiego, dobrego - np. w opowiadaniu „Umierający paser”, który „pracuje” z marzeniem o własnym synu jako ideą przewodnią życia.

Pobłażliwie i dobrotliwie traktuje autor również przedstawicieli władzy i prawa - ukazując milicjantów jako ludzi dobrodusznych, naiwnych, traktujących swych „pensjonariuszy” jako niepoprawnych łobuzów.

Wychowawczo opowiadania te nie oddziałują tak, jak powinny, gdyż nie ukazują całej społecznej szkodliwości tych środowisk, nie odsłaniają w sposób odstręczający całej brzydoty, amoralności ich życia. Jedyna nauka moralna, jaka z ich płynie - to pokazanie, że każdego złodzieja prędzej, czy później czeka więzienie. I tym należy się zadowolić i to (nieczytelne) nie uzasadnia celowości wydania pozycji. Literacko opowiadania robione są trochę pod realizm Hłaski, ale ten w gorszym wydaniu.

Opowiadanie „Przymałe buty”- s. 157-168 ukazujące środowisko dworcowych włóczęgów, wymaga przeredagowania, gdyż mamy tu zbyt koszmarny obraz ich nędzy ${ }^{9}$.

Ostatecznie dopuszcza się tom do druku, utrzymując jednak zmiany w opowiadaniu Przymałe buty: „[...] Ponieważw tym tekście nie można dokonać po prostuingerencji-stwierdza anonimowa zwierzchniczka - dopisek K. B. - prosiłam tow. Kopińską, aby wydawca przejrzał całe opowiadanie i zaproponował nowy tekst. Na mój wniosek otrzymałam zgodę 6 listopada 1958 r.", podpis nieczytelny ${ }^{10}$. Zezwala się na druk już następnego dnia, najwyraźniej wydawca (autor?) dostarczył przeredagowane opowiadanie. W związku z tym, że Przymałe buty nie były wcześniej publikowane w prasie, nie ma możliwości porównania drukowanych wersji tekstu, a przekazana cenzurze składka, niestety, się nie zachowała. Możemy jedynie przypuszczać, że przeróbki dotyczyły stonowania obrazu nędzy i beznadziejności życia bezdomnych. Warto tu zwrócić uwagę na niezwykłą szybkość (1 dzień!) dostarczenia urzędowi kontroli nowej postaci utworu. Można przypuszczać, że albo dokonano zmian kosmetycznych, które Mysią jednakże zadowoliły, albo „łagodniejsza” wersja opowiadania była przygotowana już wcześniej.

O domniemanym charakterze zmian w Przymatych butach można wnioskować na podstawie opowiadania Trzyczwartak. Zachowało się bowiem kilka wersji tekstu, różniących się od siebie znacząco: postać drukowana w „Twórczości” w kwietniu 1958 roku, opowiadanie wydane w czytelnikowskim zbiorze oraz - najciekawsza dla niniejszych rozważań cenzorska korekta sporządzona przed ogłoszeniem utworu w „Twórczości”. Oprócz drobnych zmian redakcyjnych, gdy na przykład „gałganianą lalkę” zamieniono na „gałgankową”, w druku pojawiają się wyraźne zmiany o charakterze cenzuralnym, przy czym głębiej ocenzurowana jest wersja z „Twórczości”, a powierzchowniej wersja książkowa. Takie istotne przekształcanie tekstu, który ma się ukazać w wysokonakładowym czasopiśmie, a mniej ostra kontrola wersji przygotowanej do wydania w trudno dostępnym na rynku (nikły nakład) tomiku, było jedną z częściej stosowanych przez GUKPPiW strategii ${ }^{11}$.

${ }^{9}$ AAN, GUKPPiW, 596, teczka 68/3, k. 300-301. W artykule przyjęłam następujące zasady cytowania źródeł: modyfikacji ortografii i interpunkcji towarzyszy zachowanie oryginalnej składni.

10 Ibidem.

${ }^{11}$ Na ten temat, K. Budrowska, Literatura i pisarze wobec cenzury PRL 1948-1958, Białystok 2009, s. 93 i n. 


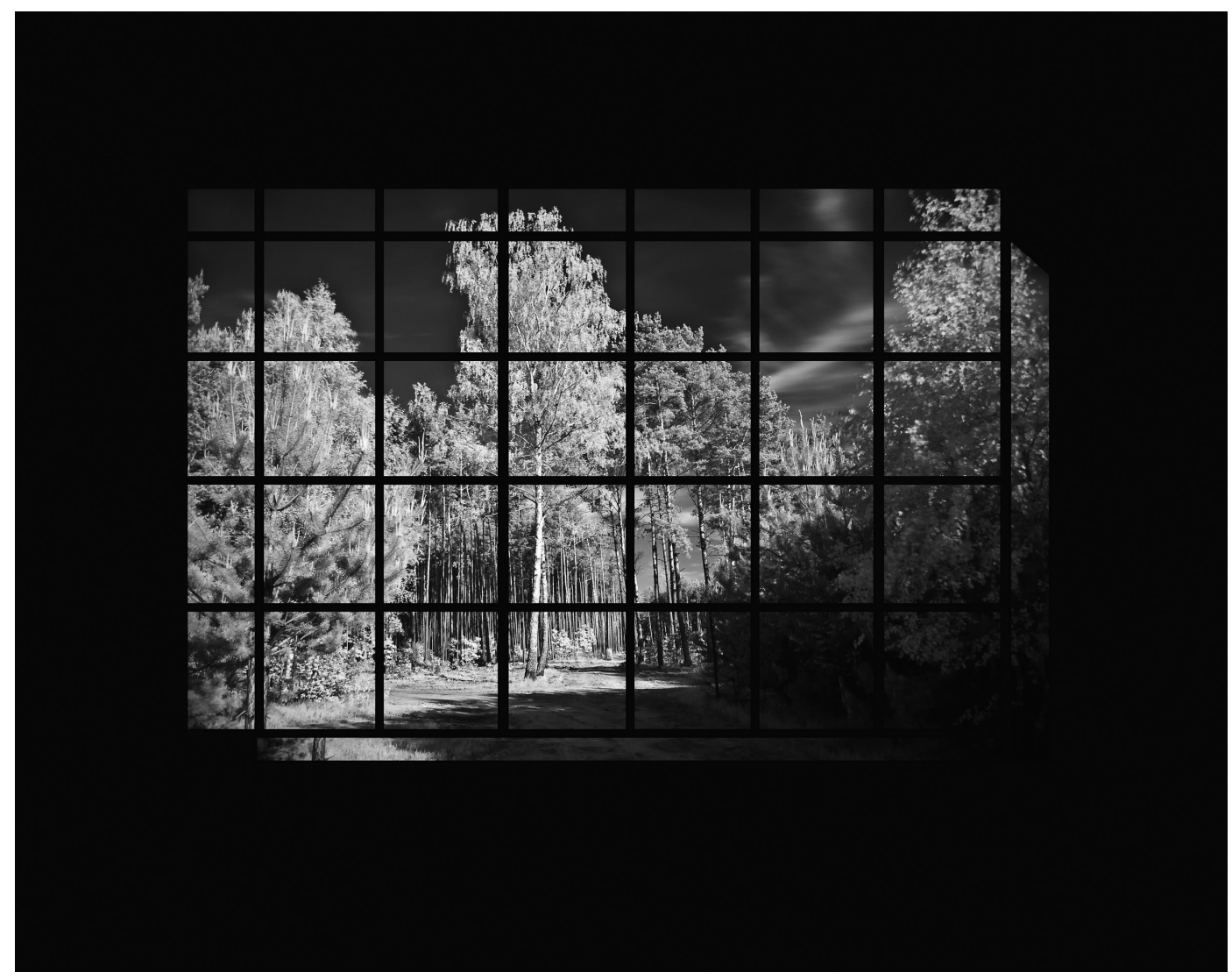

Przestrzeń - 003

Ingerencje w Trzyczwartaku dotyczą drastyczności wysłowienia (wycina się wulgaryzmy i proponuje w ich miejsce słowa mniej obsceniczne) oraz dosłowności w opisie stosunków seksualnych oraz późniejszych relacji na ich temat (tu podobnie: zamiana słów lub wycinanie niektórych kwestii). Wprowadzone przez GUKPPiW zmiany lagodzą wymowę tekstu, zmniejszają jego drastyczność. Powodują też mniejszą zrozumiałość niektórych dialogów i, rzecz jasna, zmniejszają wiarygodność językową postaci: trudno przypuszczać, by przedstawiciele lumpenproletariatu szczególnie przebierali w słowach, zwłaszcza w rozmowach prowadzonych między sobą.

Podobnie skomplikowana sytuacja edytorska zaistnieje w przypadku tekstu Kazimiery Iłłakowiczówny. „Sygnał” 54 z 1958 roku zawiera informację o wycięciu w całości z czasopisma „Orka” (nr 34 z 1958 r.) wiersza Jest $w$ Poznaniu... oraz przytacza sam utwór ${ }^{12}$. Tekst dotyczy młodego robotnika Gulczyńskiego, biorącego udział w strajkach robotniczych z czerwca 1956 roku (podtytul: Poświęcone ryzykantowi, który niedawno wsiadt na Pegaza umieszczonego na dachu opery $w$ Poznaniu). Zdaniem cenzorów w związku z poruszaną problematyką wiersz nie nadaje się dla masowego odbiorcy (prasa). Może natomiast ukazać się w druku, jak zapowiadają „Sygnały”, w tomiku Lekkomyślne serce ${ }^{13}$.

\footnotetext{
12 AAN, GUKPPiW, 594, teczka 62/2, k. 231-232.

13 K. Iłłakowiczówna, Lekkomyślne serce, Warszawa 1959, s. 22-23.
} 
Wiersz rzeczywiście znalazł się w wydanym przez „Czytelnika” w 1959 roku elitarnym tomie (nakład „Orki” w 1958 roku wynosił 21250 egzemplarzy i przekraczał ponad 10-krotnie nakład tomu Lekkomyślne serce). Pojawia się więc podobna strategia kontroli co przy opowiadaniach Nowakowskiego: zmniejszanie potencjalnej grupy odbiorców oraz, dodatkowo, jeszcze jedna operacja - przesuwanie wydania w czasie, by utwór jak najbardziej się zdezaktualizował.

Sama poetka nie była przez władze hołubiona, więc na jej twórczość zwracano baczną uwagę. Znalazła się $\mathrm{w}$ gronie autorek na tyle kontrowersyjnych, by w wewnętrznych pismach cenzury poświęcić jej obszerny tekst instruktażowy. W 1955 roku w „Biuletynie Informacyjno-Instrukcyjnym" czytamy:

Ponieważ stosunkowo obfity dorobek poetycki Iłłakowiczówny jest u nas mało znany, a w ostatnich czasach niektóre wydawnictwa katolickie czynią usilne próby wydania części jej wierszy (PAX 1954, Pallotinum 1955), zachodzi potrzeba zwrócenia uwagi na dorobek poetycki oraz problematykę jej twórczości. Orientacja ta jest potrzebna w konkretnej pracy cenzorskiej ${ }^{14}$.

$\mathrm{W}$ artykule tendencyjnie zarysowano sylwetkę oraz dorobek autorki Ikarowych lotów, podkreślając jej „bezgraniczne i ślepe wprost uwielbienie dla późniejszego Marszałka” (s. 352) oraz „bezgraniczną głupotę” w ocenie Związku Radzieckiego (s. 354). „Ocena polityczna” wierszy także nie wypada pomyślnie: pisarka nie napisała żadnego tekstu, który afirmowałby Polskę Ludową, a w wielu przebijają „nutki tęsknoty, oczekiwania dawnej szlacheckiej świetności i szumu husarskich skrzydeł” (s. 359). Autor szkicu, cenzor Królik, konkluduje: „Dlatego też fakt pozytywnych stron w twórczości Iłłakowiczówny (oparcie wypowiedzi poetyckiej na wzorcach ludowej pieśni i gawędy - K. B.) nie może przesłaniać tego, z czym absolutnie zgodzić się nie możemy"15. Artykuł prawdopodobnie został sprowokowany dwoma zbiorami wierszy religijnych poetki: w 1954 roku PAX wydał Poezje. 1940-1954, a w 1955 roku Wiersze religijne. 1912-1954 opublikowało poznańskie wydawnictwo „Albertinum” (a więc nie - „Pallotinum”, jak chciał cenzor) ${ }^{16}$. Wydawnictwa państwowe w latach stalinowskich nic Iłłakowiczównie nie ogłosiły, zmiana nastąpiła dopiero w 1957, gdy PIW opublikował prozę poetycką Z rozbitego fotoplastikonu. Lekkomyślne serce wydane zostało więc na fali spóźnionej „odwilży”.

Jak wynika z akt wydawniczych „Czytelnika”, końcowe zezwolenie na druk tomiku przychodzi 8 grudnia 1958 roku $^{17}$, jednakże w adnotacji sporządzonej pod koniec miesiąca czytamy jeszcze o zastrzeżeniach:

W zbiorze K. Iłłakowiczówny zakwestionowane przez tow. Szymanko wiersze na stronach 12, $22,28,104,125,149,150 / 151,160$ konsultowałem z tow. Strasserem. Ustalono, że należy ingerować na stronach 22 - motto wiersza "Jest w Poznaniu”, na s. 129 - wiersz „W Poznaniu na wygnaniu”, s. 160 - „Kości”. Tow. Strasser zakwestionował również zakończenie fraszki na s. 104. Ostatecznej decyzji jeszcze nie podjęto. Ingerencje omówił tow. Strasser z tow. Kosińskim ${ }^{18}$.

\footnotetext{
${ }^{14}$ AAN, GUKPPiW, 420, teczka 165/4, k. 351.

15 Ibidem, k. 363.

${ }^{16}$ Współcześni polscy pisarze i badacze literatury. Słownik biobliograficzny, red. J. Czachowska, A. Szałagan, t. 3, Warszawa 1994, s. 296.

17 AAN, GUKPPiW, 596, teczka 68/3, k. 184.

18 Ibidem, k. 158.
} 
Z kolejnego wpisu wynika, że ingerencje utrzymano jedynie na stronach 150/151 i 160, co potwierdzają także oględziny tomiku. Motto ze strony 22 zostało bez zmian, zachowany został także wiersz $W$ Poznaniu na wygnaniu - wprawdzie nie na stronie 129, ale 149.

Na stronach 150/151 znajduje się tekst Matka Boska Świętomarcińska, a na stronie 160 - Kości. Trudno jednoznacznie wnioskować, czego mogły dotyczyć utrzymane ingerencje, nie zachowały się ani żadne informacje na ten temat, ani przekazana cenzurze materialna postać tekstów. Prawdopodobnie mogło chodzić o stonowanie kwestii zniszczenia przez „łobuzów” figurki Matki Boskiej Świętomarcińskiej, a w wierszu Kości, przynoszącym obraz lip płaczących nad pochowanymi pod nimi nieznanymi kośćmi, „kośćmi nieśmiertelnej chwały" - analogii do wojny i anonimowych bohaterów. Możliwe, że w pierwotnej wersji tekstu pojawiła się większa dosłowność oskarżenia lub identyfikacji oprawców.

„Sygnal” nr 27 z 22 kwietnia 1960 roku zawiera interesującą informację na temat opowiadania Włodzimierza Odojewskiego Nim raz drugi wstanie świt ${ }^{19}$. Historia cenzurowania tekstu wydaje się na tyle złożona, że warto ją pokrótce przypomnieć. Jak podaje słownik Wspótcześni polscy pisarze i badacze literatury, wzmiankowane opowiadanie zostało zgłoszone do druku przez „Wydawnictwo Poznańskie” jako część zbioru Codzienna ściana płaczu, który w całości zatrzymała cenzura ${ }^{20}$. Do kontroli tomu doszło w 1958 roku, w aktach „Wydawnictwa Poznańskiego” zachowały się nie tylko negatywne recenzje, ale także kompletne maszynopisy dwóch najbardziej niecenzuralnych utworów: Nim raz drugi wstanie świt (w materiałach cenzorskich nieprecyzyjny tytul) oraz Droga. Do druku Nim raz drugi wstanie świt dojdzie ostatecznie dopiero w 1962 roku w zbiorze Zmierzch świata ${ }^{21}$.

W „Sygnałach 1960” opowiadanie nie zostało zaprezentowane w całości, pomieszczono jedynie bardzo drastyczny, półtorastronicowy fragment. Notatka przed tekstem głosi:

W nrze 8 z 15 IV br. we „Współczesności” zostało zatrzymane w całości opowiadanie W. Odojewskiego „Nim raz drugi wstanie świt”. Treścią tego opowiadania są wspomnienia rannego żołnierza WP wyczekującego na pomoc kolegów w czasie walki z bandą UPA. We wspomnieniach tych przewijają się sceny walk stoczonych z UPA, sceny okrucieństw i zawziętości UP-owców, które z drugiej strony rodzą u żołnierzy zawziętość i bezwzględność w stosunku do bandytów i sprzyjającej im ludności ukraińskiej. Żołnierze, stykając się wciąż z okrutnymi morderstwami dokonywanymi przez UP-owców, odpowiadają na to (mimo zakazów i kar) paleniem wsi ukraińskich, masowym rozstrzeliwaniem jeńców, gwałceniem kobiet. Całe opowiadanie przepojone jest atmosferą niesłychanej nienawiści. Niżej podajemy fragment tego opowiadania $[\ldots]^{22}$.

Zamieszczono fragment rozpoczynający się od słów: „Już maszerował drogą w rozciągniętej luźno kolumnie [...] aż do [...] a później już było wiele dróg i wiele wsi, gdzie robili to samo, mimo zakazów, kar [...]”. Jak się okazuje, wersja opublikowana w 1962 roku została wyraźnie przekształcona, co można prześledzić nawet na podstawie tak krótkiego, jak ten zamieszczony w „Sygnałach”, fragmentu. Zredukowano drastyczność opisów: „obcięte piersi kobiece” zamieniono na „okrutne okaleczenie”, skrócono opis nagości gwałconej dziewczyny, zmieniono zasadniczo fragment zdania: „a później już było wiele dróg i wiele wsi, gdzie robili to samo, mimo zakazów, kar (podkr. K. B.)” na: „a później już było

\footnotetext{
19 AAN, GUKPPiW, 594, teczka 62/4, k. 87-88.

20 Współcześni polscy pisarze i badacze literatury..., t. 6, Warszawa 1999, s. 124.

21 W. Odojewski, Nim raz drugi wstanie świt, [w:] idem, Zmierzch świata, Warszawa 1962, s. 199-213.

22 AAN, GUKPPiW, 594, teczka 62/4, k. 87-88.
}

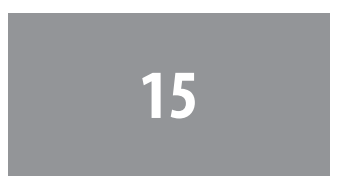


wiele takich dróg i wiele takich wsi, gdzie w s z ę d z i e to s a m o (podkr. K. B.)”. Pełny opis zmian, który wykracza poza tematykę niniejszego artykułu, byłby ciekawym zadaniem badawczym, co można postawić jako postulat dalszych prac.

Analizując „Sygnał” dotyczący opowiadania Odojewskiego, warto zwrócić uwagę na dwa fakty. Po pierwsze, poświadcza on kolejną - po Codziennej ścianie płaczu - nieudaną próbę opublikowania opowiadania, tym razem we „Współczesności”. Po drugie, cenzorska notatka bardzo wyraźnie interpretuje tekst: „Całe opowiadanie przepojone jest atmosferą niesłychanej nienawiści”, a zamieszczenie tylko kilku, bardzo okrutnych, scen utwierdza odbiorcę w prawdziwości owej wykładni.

Jeżeli odwołamy się do słownikowej definicji terminu „manipulacja”, rozumianej jako kierowanie kimś bez jego wiedzy, posługiwanie się kimś/czymś w celu osiągnięcia określonych celów ${ }^{23}$, kwestia świadomości podmiotu i przedmiotu działań wydaje się najistotniejsza. I ona także jest kluczem do zrozumienia specyfiki cenzorskiej manipulacji tekstem literackim. Każdy tekst zgłoszony do GUKPPiW podlegał specyficznej „obróbce” - dostosowywaniu go do określonych dyrektyw. Wytyczne takie nie były oficjalnie publikowane, autorzy musieli sami się ich domyślić, a pomagały im w tym instytucje wydawnicze. W okresie odwilży „zwolniono” niektóre tematy z listy zakazów, przede wszystkim „niewygodne” fakty i ujęcia tematyki okupacyjnej (okupacja radziecka, Powstanie Warszawskie, wojenne i powojenne losy żołnierzy AK, drastyczność przedstawienia, naturalizm). Kolejnym dopuszczonym czasowo kręgiem tematycznym okazały się krytyczne opisy polskiej rzeczywistości powojennej: ubóstwo, głód, niesprawiedliwość społeczna, a także „rozrachunek” $\mathrm{z}$ okresem stalinowskim. Wszystkie te treści będą z powrotem niecenzuralne już przy końcu 1957 roku.

Przyjrzenie się przedstawionym w artykule trzem historiom edytorskim pozwala wyróżnić kilka sposobów i poziomów manipulacji, które zbiorczo dają pojęcie o charakterystycznym dla PRL-owskiej cenzury stosunku do tekstu literackiego, w tym także wysokoartystycznego. Opowiadania $\mathrm{z}$ tomu Ten stary złodziej pojawiają się w dwóch wersjach drukowanych - innej w prasie, innej w książce. Cięcia i zmiany dotyczą obrazów nędzy, beznadziejności losu, a także kwestii obyczajowych. Aktualny politycznie wiersz Jest w Poznaniu Kazimiery Iłłakowiczówny nie może ukazać się w prasie, ale może w tomie poezji, spóźnionym w stosunku do daty powstania utworu aż o 3 lata. Ponadto jest w całości zacytowany w cenzorskich materiałach instruktażowych. Wszystkie wojenne opowiadania Odojewskiego budzą zastrzeżenia urzędu kontroli, który rozsypuje w 1958 roku zbiór Codzienna ściana płaczu. Najbardziej drastyczne z nich - Nim raz drugi wstanie świt... - zostaje zgłoszone dwa lata później do druku we „Współczesności”, gdzie ponownie nie przechodzi przez sito kontroli. Ukazuje się dopiero w 1962 roku, ale na podstawie materiałów zachowanych $\mathrm{w}$ archiwum można stwierdzić, iż w opublikowanej wersji dokonano wielu zmian „łagodzących” opisy mordów dokonywanych na ludności cywilnej przez polskich i ukraińskich żołnierzy. Kilka drastycznych scen, poprzedzonych wyraźnie interpretującym komentarzem, zostało przywołanych w „Sygnałach”.

Mamy więc tu do czynienia $\mathrm{z}$ bezpośrednim manipulowaniem treścią poprzez prowadzone zmiany i cięcia (Nowakowski, Odojewski), manipulowaniem liczbą odbiorców (Nowakowski, Iłłakowiczówna, Odojewski), opóźnianiem druku (Iłłakowiczówna, Odojew-

${ }^{23}$ Mały słownikjęzyka polskiego, red. E. Sobol, Warszawa 1997, s. 418. 
ski), zmianą układu w obrębie tomu (Odojewski). GUKPPiW pośrednio manipuluje także autorami, wpływając, a raczej wymuszając na nich decyzje odnośnie do kształtu dzieła.

Ustalając artystyczne hierarchie - pisze Marta Fik - cenzor przekracza wąską w końcu rolę „współautora” konkretnego dzieła; [...] staje się kimś więcej niż osobą mającą wpływ na kształt tej, czy innej książki, filmu czy spektaklu. Współkreuje rzeczywistość kulturalną - zarówno gdy idzie o dokonania bieżące, jak i historię $e^{24}$.

W przypadku cenzurowania wzmiankowanych tekstów zadaniem, do którego się dąży, jest wykreowanie określonej wersji najnowszej historii Polski - sprzecznej z doświadczeniem społecznym i pamięcią. Ale cel nadrzędny tak skomplikowanych operacji zdaje się zakrojony znacznie szerzej: stworzenie alternatywnej, wobec zastanej rzeczywistości, wizji świata, utrzymanie w społeczeństwie pewnego stopnia niewiedzy, i najważniejsze - tworzenie norm ${ }^{25}$.

Opisane operacje przeprowadzane na opowiadaniach Marka Nowakowskiego, Włodzimierza Odojewskiego czy wierszach Kazimiery Iłłakowiczówny nie wyczerpują repertuaru $\mathrm{n}$ i e s t o s o w n y h z a s t o s o w a ń tekstu literackiego. To dlatego w artykule posłużyłam się przykładami zamieszczonymi w cenzorskich materiałach instruktażowych. O ile bowiem kontrolowanie dzieła literackiego odbywa się za wiedzą autora, o tyle wykorzystywanie jego utworów w celach instruktażowych - już nie.

Chcąc wydać tekst w oficjalnym obiegu, pisarze godzili się z faktem cenzorskiej lektury i oceny. Wiedzieli, że urzędnicy opresywnej instytucji przełamać mogą jego integralność, co groziło zwłaszcza przy poruszaniu kontrowersyjnej, na przykład „odwilżowej”, tematyki. Zgadzali się na p r z e k s z t a ł c a n i e tekstu literackiego, ale takie, by zachowana została jego nadrzędna funkcja estetyczna (utwór, wprawdzie zmieniony, publikuje się jako pełną, zamkniętą całość). Zgadzali na pierwszy poziom manipulacji.

Ogłoszenie drukiem wymienionych w artykule dzieł nie kończyło jednak ich peregrynacji w GUKPPiW. Poddano je jeszcze dodatkowej „obróbce” i wykorzystano jako materiał szkoleniowy dla cenzorów. O fakcie ich ogłoszenia, w całości lub we fragmentach, w biuletynach wewnętrznych urzędu autorzy wiedzieć, rzecz jasna, nie mogli. Mamy więc tu do czynienia z głębszym poziomem manipulacji - p o sł u ż en i e m się tekstem, po pierwsze, bez świadomości autora, po drugie - w celach innych niż estetyczne. Cel bowiem takiej procedury był ściśle dydaktyczny: instruktaż w zakresie tego, co zakazane, oraz projektowanie pożądanych tematów i poetyk.

Uwidacznia się więc pewien paradoks sytuacji: znakomite artystycznie i ważne problemowo teksty o tematyce dopuszczonej do publikacji na krótko w okresie Października stanowią podstawę do tego, by stworzyć nowe wytyczne i nauczyć cenzorów, jak już pisać nie wolno. I to jest chyba wyrazisty przykład „braku dostępu do świata alternatywnego”, o którym piszą, w odniesieniu do czasów PRL, badacze ${ }^{26}$.

${ }^{24}$ M. Fik, Cenzor jako współautor, [w:] Literatura i władza, wstęp E. Sarnowska-Temeriusz, Warszawa 1996, s. 143.

25 U. Otto, Cenzura literatury. Rozważania teoretyczne woparciu o teorię Vilfredo Pareto, [w:] Cenzura w Niemczech wXX wieku. Studia, analizy, dokumenty, wyb., tłum. C. Karolak, Poznań 2000, s. 434-455.

${ }^{26}$ M. Mazur, Propagandowy obraz świata. Polityczne kampanie prasowe w PRL 1956-1980. Model analityczno-koncepcyjny, Warszawa 2003, s. 130 i n. 